\title{
HUBUNGAN PERILAKU KELUARGA DENGAN KETERATURAN BEROBAT KLIEN SKIZOFRENIA DI PUSKESMAS LUBUK BUAYA PADANG
}

\author{
Edo Gusdiansyah \\ Prodi S1 Keperawatan STIKES Alifah Padang \\ Email: edo.gusdiansyah@gmail.com
}

\begin{abstract}
ABSTRAK
Skizofrenia adalah penyakit yang mempengaruhi otak dan menyebabkan timbulnya pikiran, persepsi, emosi, gerakan dan perilaku yang aneh dan terganggu. Prevalensi di indonesia penderita skizofrenia sebesar 1,7 juta orang yang mengalami gangguan jiwa. Penelitian ini bertujuan untuk melihat hubungan perilaku keluarga dengan keteraturan berobat klien skizofrenia. Jenis penelitian deskriptif korelasi dengan desain cross sectional. Penelitian ini dilaksanakan di Puskesmas Lubuk Buaya Padang, Populasi adalah seluruh keluarga klien skizofrenia yang berobat di Puskesmas berjumlah 98 orang, dengan teknik total sampling dan pengumpulan data menggunakan kuesioner. Hasil penelitian menunjukkan 65,0\% klien tidak teratur berobat, 57, 5\% berpengetahuan rendah, 55,0\% sikap negatif dan 52,5\% dengan tindakan keluarga tidak baik. Hasil uji statistik menunjukkan adanya hubungan yang bermakna antara pengetahuan $(p=0,000)$, sikap keluarga $(p=0,005)$ dan tindakan keluarga $(p=0,004)$ dengan keteraturan berobat klien skizofrenia. Masih banyaknya penderita skizofrenia yang tidak teratur dalam berobat ke puskesmas. Diharapkan bagi petugas kesehatan memberikan pendidikan dan konseling. Sehingga keluarga lebih memperhatikan penderita dalam melakukan kontrol berobat dan mencari informasi.
\end{abstract}

Kata kunci : Keteraturan Berobat, Pengetahuan, Sikap dan Tindakan Keluarga

Daftar Bacaan : 49 (2004-2016)

\begin{abstract}
Schizophrenia is a disease that affects the brain and causes strange and disturbed thoughts, perceptions, emotions, movements and behaviors. Prevalence in Indonesia schizophrenia of 1.7 million people who have mental disorders. This study aims to see the relationship of family behavior with regular treatment of schizophrenic clients. The research type is descriptive correlation with cross sectional design. This research was conducted at Lubuk Buaya Public Health Center. The population was the whole family of schizophrenic clients 98 people, with total sampling technique. Data were collected using questionnaires. The results showed that $65.0 \%$ of clients were not regularly treated, 57, 5\% low knowledge, negative attitude $55.0 \%$ and $52.5 \%$ with bad family actions. The result of statistical test showed a significant correlation between knowledge $(\mathrm{p}=$ $0,000)$, family attitudes $(\mathrm{p}=0,005)$ and family action $(\mathrm{p}=0,004)$ with regular treatment of schizophrenic client. There are still many irregular schizophrenia sufferer in medication at health center. It is expected that health workers provide education and counseling. So that the family pay more attention to the patient in doing medical control and seek information.
\end{abstract}

Keywords $\quad$ : Regulation of Medicine, Knowledge, Attitude and Family Action

Reading List : :49 (2004-2016) 


\section{PENDAHULUAN}

Orang Dengan Gangguan Jiwa (ODGJ) adalah seseorang yang mengalami gangguan pikiran, perilaku dan perasaan yang dimanifestasikan dalam bentuk sindrom dan atau perubahan perilaku yang bermakna, serta dapat menimbulkan hambatan bagi klien dalam menjalankan fungsi sebagai manusia (UU Kesehatan No. 18 tahun 2014). Kesehatan jiwa adalah suatu keadaan sejahtera dikaitkan dengan kebahagian, kegembiraan, kepuasan, pencapaian, optisme, atau harapan. Beberapa pendapat menyatakan bahwa kesehatan jiwa bukanlah konsep yang sederhana atau hanya tentang satu aspek dari perilaku (Keliat, B.A \& Pasaribu, 2016). Gangguan jiwa adalah sindrom atau pola prilaku yang secara klinis bermakna yang berhubungan dengan distres atau penderitaan dan menimbulkan hendaya (prilaku menyimpang) pada satu atau lebih fungsi kehidupan manusia (Budi Anna Keliat, dkk 2011).

Masalah kesehatan jiwa secara global, prevalensi gangguan jiwa selalu meningkat dari tahun ke tahun, Menurut (WHO, 2013) menyebutkan tidak kurang dari 450 juta gangguan jiwa di temukan. Munculnya masalah gangguan jiwa di sebabkan oleh perubahan pola lingkungan, prilaku dan akibat kondisi biologik individu, individu yang rentan tersebut apabila dikenai stress psikososial seperti masalah dalam keluarga, status ekonomi yang rendah, gagal dalam mencapai cita-cita, konflik yang berlarut-larut, kematian keluarga yang di cintai dapat menjadi salah satu menyebabkan gangguan jiwa, salah satunya yaitu penyakit gangguan jiwa berat yaitu skizofrenia (Erlian, dkk, 2010) Klien dengan skizofrenia memerlukan perlakuan yang tepat, agar gejala yang dialami tidak memburuk.

Skizofrenia adalah gangguan mental kronis yang menyebabkan penderitanya mengalami delusi, halusinasi, pikiran kacau, dan perubahan perilaku. Karakteristik skizofrenia berupa adanya delusi, halusinasi, cara bicara yang tidak teratur, sikap yang tidak beraturan dan gejala negatif lainnya seperti kurangnya antusiasme, kurangnya keperdulian terhadap lingkungan sekitar dan gangguan kemampuan bicara (Keliat, 2011). Kondisi yang biasanya berlangsung lama ini sering diartikan sebagai gangguan mental mengingat sulitnya penderita membedakan antara kenyataan dengan pikiran sendiri hal ini mencerminkan disfungsi psikobiologis dan bukan sebagai akibat dari penyimpangan sosial atau konflik dengan masyarakat (Keliat, B.A \& Pasaribu, 2016). Skizofrenia bersifat kronis dialami dalam waktu yang lama dan sebagian besar dialami seumur hidup dan kambuh, (Kazadi et al, 2008).
Kekambuhan dapat terjadi akibat ketidak teraturan penderita dalam berobat.

Ketidak teraturan berobat merupakan perilaku penderita untuk menyelesaikan pengobatan sesuai dengan jadwal dan tepat waktu. Green (1980) dalam Notoadmodjo (2007) mengidentifikasikan tiga faktor yang mempengaruhi perilaku kesehatan yaitu faktor predisposisi, faktor pemungkiman, faktor penguat. Yang termasuk faktor predisposisi antara lain pengetahuan, sikap, keyakinan, nilai persepsi. Yang termasuk faktor pemungkiman adalah ketersedian sumber daya, keterjangkauan petugas dan rujukan. Sedangkan yang termasuk faktor penguat antara lain sikap dan perilaku petugas kesehatan dan petugas lainnya, majikan, dan orang tua (Notoadmodjo, 2007).

Dampak dari ketidakteraturan berobat mengakibatkan masalah baru pada pasien skizofrenia yaitu pasien lebih mudah jatuh ke dalam kondisi kekambuhan fase psikosis yang lebih buruk, keluar masuk rumah sakit berulang kali, serta peningkatan beban sosial dan ekonomi bagi keluarga pasien (Kazadi et al, 2008). Dampak skizofrenia bagi klien adalah klien kurang semangat, klien sering mengasingkan diri dari lingkungan, berkata-kata tidak wajar (kotor), klien sering mengamuk dan potensi bunuh diri (Arie Mega Partiwi, 2009).

Jika tidak dilakukan terapi atau pengobatan dapat menimbulkan kekambuhan bagi klien (Lane, 2013). Dampak skizofrenia bagi keluarga antara lain keluarga mengalami beban dalam merawat anggota keluarga yang menderita skizofrenia, beban tersebut berupa keuangan, gangguan kegiatan keluarga, gangguan rekreasi keluarga, gangguan interaksi keluarga, efek pada kesehatan fisik dan mental. Penderita yang sakit tidak melakukan kegiatan seperti bekerja, sekolah dan juga membantu keluarga. Sehinga keluarga banyak menghabiskan waktu untuk mengurus anggota yang sakit, biaya untuk pengobatan (Maglino, 2006). Kekambuhan tersebut dapat dicegah dengan keteraturan berobat, ketidak teraturan berobat merupakan masalah prilaku.

Perilaku adalah merupakan keseluruhan (totalitas) pemahaman dan aktivitas seseorang yang merupakan hasil bersama antara faktor internal dan eksternal (Notoatmodjo, 2010). Dalam perkembangan bloom ada tiga perilaku yaitu pengetahuan, sikap dan tindakan. Pengetahuan keluarga tentang perawatan sangat penting karena keluarga mempunyai pengetahuan yang luas akan mudah memperoleh informasi untuk pasien gangguan jiwa Skizofrenia dalam perawatan. Makin tinggi pengetahuan seseorang makin mudah menerima informasi, sehingga makin banyak pula pengetahuan yang dimiliki sebaliknya 
pendidikan yang rendah akan menghambat keteraturan klien dalam berobat (Suryati, 2008). Dalam hal ini apabila seorang keluarga memiliki sikap menerima (bersedia memperhatikan stimulus) kemudian merespon terhadap apa yang diketahui tentang pentingnya memberikan dukungan, sehinga bila sikap positif secara terus menerus maka keluarga dengan motivasi dalam memberikan dukungan terhadap klien gangguan jiwa rendah bisa menjadi sedang bahkan bisa menjadi tinggi (Utami dan Marlyn, 2004).

Menurut (Notoatmodjo, 2010) Tindakan adalah aturan yang dilakukan, melakukan atau mengadakan aturan-aturan untuk mengatasi sesuatu atau perbuatan. Tindakan nampak menjadi lebih konsisten, serasi, sesuai dengan sikap (Purwanto, 1999).

Berdasarkan hasil penelitian dari Rudi Maslim dalam Mubarta (2011) prevalensi masalah kesehatan jiwa di Indonesia sebesar 6,55\%. Angka tersebut tergolong sedang dibandingkan dengan negara lainnya. Data dari 33 Rumah Sakit Jiwa ( RSJ ) yang ada di seluruh Indonesia menyebutkan hingga kini jumlah penderita gangguan jiwa berat mencapai 2,5 juta orang. Penderita gangguan jiwa berat dengan usia di atas 15 tahun di Indonesia mencapai $0,46 \%$. Hal ini berarti terdapat lebih dari 1 juta jiwa di Indonesia yang menderita gangguan jiwa berat. Berdasarkan data tersebut diketahui bahwa 11,6\% penduduk Indonesia mengalami masalah gangguan mental emosional (Riset kesehatan dasar, 2007). Sedangkan pada tahun 2013 jumlah penderita gangguan jiwa mencapai 1,7 juta (Riskesdas, 2013 ).

Data di Provinsi Sumatera Barat, prevalensi gangguan jiwa skizofrenia sebesar 1,9 permil $(17,7 \%)$, yang artinya diatas prevalensi nasional yaitu $(6,0 \%)$ (Riskesdas, 2013). Sedangkan data dari poliklinik jiwa RSJ.HB.Sa'anin Padang sebagai rumah sakit rujukan di provinsi Sumatera Barat, angka kunjungan perbulan pasien rawat jalan skizofrenia di Sumatera Barat mengalami peningkatan dan penurunan yaitu terhitung dari bulan September 2015 sebanyak 1140 orang, Oktober 2015 sebanyak 1288 orang, November 2015 sebanyak 1120 orang, dan Desember 2015 sebanyak 1393 orang, Kemudian pada awal tahun 2016 angka kunjungan di bulan Januari sebanyak 1183 orang dan bulan Februari sebanyak 1216 orang kunjungan ke Unit Pelayanan Jiwa (UPJA) RSJ. Prof. Hb.Sa'anin Padang.

Data dari Dinas Kesehatan Kota (DKK) Padang tahun 2016 terdapat tiga puskesmas dengan kunjungan gangguan jiwa (skizofrenia) tertinggi yaitu Puskesmas Lubuk Buaya sebanyak 754 orang, sedangkan Puskesmas
Air Dingin sebanyak 689 dan Puskesmas Andalas sebanyak 506 orang. Sedangkan yang terjadi peningkatan kunjungan dengan gangguan jiwa skizofrenia yang signifikan di tahun 2016 yaitu Puskesmas Lubuk Buaya.

Berdasarkan uraian di atas menunjukkan bahwa secara umum dapat dilihat bahwa hubungan perilaku dengan keteraturan berobat pasien gangguan jiwa merupakan hal-hal yang penting dan perlu diperhatikan. Untuk itu peneliti melakukan penelitian tentang "Hubungan perilaku dengan keteraturan berobat penderita skizofrenia di Puskesmas".

\section{METODE PENELITIAN}

Jenis penelitian ini adalah deskriptif korelasi yang dilakukan di Wilayah Kerja Puskesmas Lubuk Buaya Padang, Penelitian di lakukan dari bulan Mei s/d Juni 2017, dengan pengumpulan data di laksanakan selama 21 hari mulai dari tanggal 21 Mei sampai 11 Juni 2017.

Populasi pada penelitian ini adalah seluruh keluarga klien skizofrenia yang berobat di Puskesmas Lubuk Buaya Padang. Jumlah sampel dalam penelitian ini yaitu 98 orang. Teknik pengambilan sampel adalah total populasi, dengan cara door to door yaitu dari rumah ke rumah. Sampel awal pada penelitian ini yaitu 98 orang, setelah di lakukan penelitian di dapatkan sampel hanya 80 orang, 5 orang di rawat di RSJ HB Sa' anin Padang, 5 orang pindah rumah dan 8 orang lainnya tidak berada dirumah saat penelitian.

\section{HASIL DAN PEMBAHASAN}

\section{A. HASIL}

1. Distribusi Frekuensi Responden Berdasarkan Keteraturan Berobat Klien Skizofrenia

\section{Tabel.1}

Distribusi Frekuensi Responden Berdasarkan Keteraturan Berobat Klien Skizofrenia

\begin{tabular}{cccc}
\hline No & Keteraturan Berobat & $\boldsymbol{f}$ & $\mathbf{\%}$ \\
\hline 1 & Tidak Teratur & 52 & 65,0 \\
\hline 2 & Teratur & 28 & 35,0 \\
\hline & Jumlah & $\mathbf{8 0}$ & $\mathbf{1 0 0 , 0}$ \\
\hline
\end{tabular}

Berdasarkan tabel 1 dapat dilihat bahwa sebagian besar $(65,0 \%)$ klien yang tidak teratur berobat.

\section{Distribusi Frekuensi Responden Berdasarkan Pengetahuan Keluarga Klien Skizofrenia}

Tabel 2 
Distribusi Frekuensi Responden berdasarkan Pengetahuan Keluarga Klien Skizofrenia

\begin{tabular}{cccc}
\hline No & Pengetahuan & $\boldsymbol{f}$ & $\boldsymbol{\%}$ \\
\hline 1 & Rendah & 46 & 57,5 \\
\hline 2 & Tinggi & 34 & 42,5 \\
\hline & Jumlah & $\mathbf{8 0}$ & $\mathbf{1 0 0 , 0}$ \\
\hline
\end{tabular}

Berdasarkan tabel 2 dapat dilihat bahwa lebih dari separuh $(57,5 \%)$ keluarga dengan pengetahuan rendah tentang Skizofrenia.

3. Distribusi Frekuensi Responden Berdasarkan Sikap Keluarga Klien Skizofrenia

Tabel 3

Distribusi frekuensi Responden berdasarkan Sikap Keluarga Klien Skizofrenia

\begin{tabular}{cccc}
\hline No & Sikap & $\boldsymbol{f}$ & $\boldsymbol{\%}$ \\
\hline 1 & Negatif & 44 & 55,0 \\
\hline 2 & Positif & 36 & 45,0 \\
\hline & Jumlah & $\mathbf{8 0}$ & $\mathbf{1 0 0 , 0}$ \\
\hline
\end{tabular}

Berdasarkan tabel 3 dapat dilihat bahwa lebih dari separuh $(55,0 \%)$ keluarga dengan sikap negatif.

4. Distribusi Frekuensi Responden Berdasarkan Tindakan Keluarga Klien Skizofrenia

Tabel 4

Distribusi frekuensi Responden berdasarkan Tindakan Keluarga Klien Skizofrenia

\begin{tabular}{cccc}
\hline No & Tindakan & $\boldsymbol{f}$ & $\boldsymbol{\%}$ \\
\hline 1 & Tidak Baik & 42 & 52,5 \\
\hline 2 & Baik & 38 & 47,5 \\
\hline & Jumlah & $\mathbf{8 0}$ & $\mathbf{1 0 0 , 0}$ \\
\hline
\end{tabular}

Berdasarkan tabel 4 dapat dilihat bahwa lebih dari separuh $(52,5 \%)$ keluarga dengan tindakan yang tidak baik.

5. Hubungan Pengetahuan Keluarga Klien Skizofrenia dengan Keteraturan Berobat

Tabel 5

Hubungan Pengetahuan Keluarga dengan Keteraturan Berobat Klien Skizofrenia

\begin{tabular}{|c|c|c|c|c|c|c|}
\hline \multirow[t]{3}{*}{ Pengetahuan } & \multicolumn{4}{|c|}{ Keteraturan Berobat } & & \\
\hline & \multicolumn{2}{|c|}{$\begin{array}{c}\text { Tidak } \\
\text { Teratur }\end{array}$} & \multicolumn{2}{|c|}{ Teratur } & & \\
\hline & $f$ & $\%$ & $f$ & $\%$ & $f$ & $\%$ \\
\hline Rendah & 42 & 52,5 & 4 & 5 & 46 & 57,5 \\
\hline Tinggi & 10 & 12,5 & 24 & 30 & 34 & 42,5 \\
\hline
\end{tabular}
Total 52
65 28 $35 \quad 80$
100,0

Berdasarkan tabel 5 dapat dilihat bahwa proporsi keluarga yang tidak teratur berobat lebih tinggi pada keluarga dengan pengetahuan rendah $(52,5 \%)$ dibandingkan dengan keluarga pengetahuan tinggi $(12,5 \%)$. Hasil uji statistik menggunakan uji chi square didapatkan nilai $p=0,000(p<0,05)$ artinya terdapat hubungan yang bermakna pengetahuan keluarga dengan keteraturan berobat pasien skizofrenia.

6. Hubungan Sikap Keluarga Klien Skizofrenia dengan Keteraturan Berobat

Tabel 6

Hubungan Sikap Keluarga dengan Keteraturan Berobat Klien Skizofrenia Keteraturan Berobat

\begin{tabular}{ccccccc}
\multirow{2}{*}{ Sikap } & \multicolumn{2}{c}{ Tidak } & \multicolumn{2}{c}{ Teratur } & & \\
& \multicolumn{2}{c}{ Teratur } & \multicolumn{2}{c}{} & \\
& $\boldsymbol{f}$ & $\mathbf{\%}$ & $\boldsymbol{f}$ & $\mathbf{\%}$ & $\boldsymbol{f}$ & $\mathbf{\%}$ \\
\hline Negatif & 35 & 43,8 & 9 & 11,2 & 44 & 55 \\
\hline Positif & 17 & 21,2 & 19 & 23,8 & 36 &. \\
\hline Total & 52 & 65 & 28 & 35 & 80 & 100,0 \\
\hline
\end{tabular}

Berdasarkan tabel 6 dapat dilihat bahwa proporsi keluarga yang tidak teratur berobat lebih tinggi pada keluarga dengan sikap negatif $(43,8 \%)$ di bandingkan dengan keluarga sikap positif $(21,2 \%)$. Hasil uji statistik menggunakan uji chi square didapatkan nilai $p=0,005(p<0,05)$ artinya terdapat hubungan yang bermakna sikap keluarga dengan keteraturan berobat pasien skizofrenia.

7. Hubungan Tindakan Keluarga Klien Skizofrenia dengan Keteraturan Berobat

Tabel 7

Hubungan Tindakan Keluarga dengan Keteraturan Berobat Klien Skizofrenia

\begin{tabular}{ccc}
\cline { 2 - 3 } Tindakan & $\begin{array}{c}\text { Tidak } \\
\text { Teratur }\end{array}$ & Teratur
\end{tabular}

\begin{tabular}{ccccccc} 
& $\boldsymbol{f}$ & $\boldsymbol{\%}$ & $\boldsymbol{f}$ & $\mathbf{\%}$ & $\boldsymbol{f}$ & $\mathbf{\%}$ \\
\hline $\begin{array}{c}\text { Tidak } \\
\text { Baik }\end{array}$ & 34 & 42,5 & 11,2 & 10 & 42 & 52,5 \\
\hline Baik & 18 & 22,5 & 23,8 & 25 & 38 & 47,5 \\
\hline Total & 52 & 65 & 28 & 35 & 80 & 100,0 \\
\hline
\end{tabular}

Berdasarkan tabel 7 dapat dilihat bahwa proporsi keluarga yang tidak teratur berobat lebih tinggi pada keluarga dengan tindakan tidak baik $(42,5 \%)$ dibandingkan keluarga dengan tindakan baik $(22,5 \%)$. 
Hasil uji statistik menggunakan uji chi square didapatkan nilai $p=0,004(p<0,05)$ artinya terdapat hubungan yang bermakna tindakan keluarga dengan keteraturan berobat pasien skizofrenia.

\section{PEMBAHASAN}

\section{a. Keteraturan Berobat Klien Skizofrenia}

Berdasarkan hasil penelitian dapat dilihat sebagian besar $(65,0 \%)$ responden yang tidak teratur berobat.

Hasil penelitian sejalan dengan penelitian Masnona dkk (2013) menyimpulkan bahwa kepatuhan klien skizofrenia untuk melakukan kontrol berobat ke rumah sakit yang tidak patuh melakukan kontrol sebanyak $(71,3 \%)$. Penelitian ini bertentangan dengan penelitian Riska Ratnawati (2016) tentang hubungan dukungan keluarga dengan kepatuhan berobat klien skizofrenia di wilayah kerja Puskesmas Kaibon Kabupaten Madiun, menunjukkan bahwa responden yang tidak patuh berobat hanya 17 responden $(42,5 \%)$ dan 23 responden patuh berobat $(52,5 \%)$.

Ketidakteraturan berobat merupakan perilaku penderita untuk tidak menyelesaikan pengobatan sesuai dengan jadwal dan tidak tepat waktu salah-satu faktor utama keberhasilan penderita untuk sembuh. Pasien yang tidak teratur pada pengobatan akan memiliki resiko kekambuhan lebih tinggi dibandingkan dengan pasien yang teratur pada pengobatan. Ketidak teraturan berobat ini yang merupakan alasan pasien kembali dirawat (Yuliantika, 2012).

Penderita yang teratur berobat adalah yang menyelesaikan pengobatan secara teratur dan lengkap tanpa terputus selama minimal 6 bulan sampai dengan 9 bulan. Penderita dikatakan tidak teratur berobat jika tidak datang lebih dari 3 hari sampai 2 bulan dari tanggal perjanjian dan dikatakan Droup Out jika lebih dari 2 bulan berturut-turut tidak datang berobat setelah dikunjungi petugas kesehatan, kontrol artinya pemantauan, pengen dalian, pengawasan. Berarti seseorang dalam masa pengobatan tidak dibiarkan begitu saja namun perlu di pantau kembali keadaan kesehatannya namun kadang pasien datang tidak tepat waktu, dengan alasan tidak punya biaya, sibuk bekerja, sering lupa karena tidak control (Depkes RI, 2006).

Menurut analisa peneliti dalam penelitian ini didapatkan klien tidak teratur berobat yaitu $65,0 \%$.
Hasil wawancara yang di lakukan peneliti dengan keluarga responden disebabkan karena keluarga sibuk dengan pekerjaan sehari-hari sehingga untuk melakukan kontrol atau pengambilan obat sering tidak tepat waktu, kebanyakan keluarga mempunyai pekerjaan swasta yaitu 55 orang (69\%) dan mereka bosan menunggu antrian di puskesmas saat membawa keluarganya berobat ke puskesmas, dan hal tersebut menggangu pekerjaan sehari-hari Sehinga hal ini mengakibatkan ketidakteraturan klien atau keluarga dalam melakukan kontrol berobat secara teratur.

\section{b. Pengetahuan Keluarga Klien Skizofrenia}

Berdasarkan hasil penelitian dapat dilihat bahwa dari 80 orang responden terdapat lebih dari separuh $(57,5 \%)$ responden dengan pengetahuan rendah.

Hasil penelitian ini didukung oleh Edi Purnomo dkk (2016) menyebutkan bahwa Responden yang memiliki pengetahuan kurang tentang gangguan jiwa yaitu $80 \%$. Hal ini menunjukan bahwa ketidaktahuan atau kurangnya pengetahuan keluarga dalam mengenal masalah gangguan jiwa pada anggota keluarganya. Penelitian ini bertentangan dengan penelitian Kiky Alifathul Nondyawati (2015) tentang hubungan pengetahuan dan sikap dengan motivasi keluarga dalam memberikan dukungan pada klien Gangguan Jiwa menunjukkan bahwa hampir seluruh responden $(78,9 \%)$ memiliki pengetahuan kurang.

Hasil dari kuesioner, di dapatkan $41,25 \%$ tidak mengetahui tentang gangguan jiwa, 46,25\% tidak mengetahui penyebab dari gangguan jiwa, dan $48,75 \%$ tidak mengetahui perlakuan yang harus di berikan kepada anggota keluarga gangguan jiwa setelah kembali dari Rumah Sakit Jiwa. Kurangnya pengetahuan keluarga disebabkan oleh faktor eksternal dan internal seperti kurang terpaparnya keluarga terhadap informasi kesehatan jiwa dan inisiatif dari keluarga dalam mencari informasi tentang gangguan jiwa baik dari media massa, media cetak maupun elektronik. Informasi juga dapat diperoleh dari penyuluhan dan pendidikan kesehatan, baik yang dilakukan secara langsung maupun tidak langsung.

Informasi kesehatan yang didapat keluarga untuk lebih mengetahui, mengerti dan memahami tentang gangguan jiwa skizofrenia sehingga pada akhirnya dapat berperan secara aktif sebagai pendukung pertama bagi pasien. Hal ini tentu saja 
meningkatkan kemampuan penyesuaian diri pasien serta tidak rentan lagi terhadap pengaruh stressor psikososial. Pengetahuan keluarga dalam memberikan perawatan dibuktikan dengan pendidikan keluarga yang baik dan bagaimana keluarga mampu memahami kondisi dan mencukupi kebutuhan pasien skizofrenia. Sesuai dengan penelitian dari badan National Mental Health Assosiation (2001) menyebutkan bahwa keluarga menganggap seseorang yang mengalami gangguan jiwa tidak akan pernah sembuh lagi, tingkah laku nya tidak dapat diprediksi dan cenderung berbahaya

Menurut analisa peneliti dalam penelitian ini ketidaktahuan keluarga ini disebabkan karena informasi yang diperoleh tidak menyeluruh. Kurang informasi ini dikarenakan ketidakaktifan keluarga dalam memperoleh informasi baik dari petugas maupun dari media massa lainnya sehingga keluarga terkesan acuh dan tidak memperhatikan hal-hal yang perlu diperhatikan dalam perawatan klien gangguan jiwa dirumah. Salah satu hal yang dapat mempengaruhi pengetahuan adalah pendidikan, semakin tinggi tingkat pendidikan seseorang maka semakin tinggi pula pengetahuannya. Perhatian tersebut dapat diwujudkan dengan pengaktifan Kader di setiap wilayah kerja Puskesmas Lubuk Buaya Padang yang berguna untuk memberikan informasi dan pengalaman kepada keluarga dengan gangguan

\section{c. Sikap Keluarga Klien Skizofrenia}

Berdasarkan hasil penelitian dapat dilihat bahwa dari 80 orang responden terdapat lebih dari separoh $(55,0 \%)$ responden dengan sikap negatif.

Penelitian ini sesuai dengan penelitian Fitri Lestari dkk (2010) menunjukkan banyak responden yang masih memiliki persepsi tentang gangguan jiwa secara negatif yaitu $50(52,1 \%)$. Sejalan dengan penelitian Kiky Alifathul Nondyawati (2015) yang menyebutkan bahwa lebih dari separuh $(78,9 \%)$ memiliki sikap negatif dengan motivasi dalam memberikan dukungan terhadap klien gangguan jiwa rendah dan sebagian kecil responden memiliki sikap positif dengan motivasi dalam memberikan dukungan terhadap klien gangguan jiwa tinggi yaitu $(5,3 \%)$.

Seorang keluarga yang memiliki sikap menerima (bersedia memperhatikan stimulus) kemudian merespon terhadap apa yang diketahui tentang pentingnya memberikan dukungan, sehingga bila sikap positif secara terus menerus maka keluarga dengan motivasi dalam memberikan dukungan terhadap klien gangguan jiwa rendah bisa menjadi sedang bahkan tinggi, dalam proses pembentukan sikap dipengaruhi oleh beberapa faktor yaitu pengalaman pribadi, pengaruh orang lain yang dianggap penting, pengaruh kebudayaan, media massa, lembaga agama dan pengaruh emosional (Azwar, 2005).

Sikap positif yang harus dilakukan oleh keluarga dalam upaya penyesuaian diri dengan kehadiran anggota keluarga yang gangguan jiwa adalah keluarga aktif dalam mencari informasi, sikap yang SAFE (Sense of humor, Accepting the illnes, Famili balance, Expectation which are realistic), terapi keluarga dan keluarga harus mampu membantu menumbuhkan sikap mandiri dalam diri pasien dengan kesabaran dan menerima kenyataan. Sikap keluarga dalam hal ini adalah tanggapan atau reaksi keluarga untuk bertindak terhadap anggota keluarga gangguan jiwa skizofrenia, seperti bagaimana tanggapan keluarga jika anggota keluarga skizofrenia mengamuk dirumah serta bagaimana tanggapan dalam menghadapi perubahan positif anggota keluarga yang skizofrenia.

Menurut analisa peneliti sikap yang baik suatu bentuk evaluasi atau reaksi perasaan. Sikap seseorang terhadap suatu objek. Hal ini terjadi karena keluarga responden dengan pendidikan yang masih dalam kategori rendah, menjadikan persepsi tentang penyakit gangguan jiwa sulit untuk disembuhkan atau tidak dapat disembuhkan.

Berdasarkan wawancara yang peneliti lakukan kepada keluarga klien gangguan jiwa terdapat rata-rata pendidikan terakhir keluarga yaitu SMA ada 44 orang (55\%) dengan rentang umur $26-60$ tahun. Selain itu, pada zaman sekarang keluarga bekerja untuk meningkatkan status ekonomi dan menambah penghasilan keluarga, sehingga pengobatan pada klien gangguan jiwa untuk melakukan kontrol berobat sering di abaikan. Hal ini berdampak pada klien gangguan jiwa untuk melakukan kontrol berobat tidak teratur karena keluarga sibuk bekerja dan tidak mempunyai waktu luang untuk membawa klien gangguan jiwa ke Puskesmas.

\section{d. Tindakan Keluarga Klien Skizofrenia}

Berdasarkan hasil penelitian dapat dilihat bahwa dari 80 orang responden terdapat lebih dari separuh $(52,5 \%)$ responden dengan tindakan yang tidak baik. 
Penelitian ini sesuai dengan penelitian Regina tentang tindakan atau dukungan keluarga klien skizofrenia sebesar 46 responden atau (48,9\%), dengan dukungan yang tinggi akan lebih berhasil dalam menghadapi dan mengatasi masalahnya. Penelitian ini sejalan dengan penelitian Masnona dkk (2013) tentang hubungan dukungan keluarga dengan kunjungan kontrol pasien jiwa skizofrenia di rawat jalan di RSJ Provinsi Lampung menunjukkan bahwa dukungan keluarga pada pasien jiwa skizofrenia lebih tinggi pada kategori tidak mendukung sebesar 64 orang $(59,3 \%)$.

Menurut Silvia (2008) tindakan atau dukungan anggota keluarga pada penderita berupa dorongan, memberikan semangat dan inspirasi, memperlihatkan kepercayaan pada perbaikan perilaku kesehatan. Dukungan diberikan setelah anggota keluarga mengetahui tujuan dari dukungan yang diberikan dan mengetahui bentuk dukungan yang akan diberikan. Hasil dari kuesioner, di dapatkan (96\%) keluarga tidak bersedia menyiapkan waktu luang, saat penderita ingin melakukan kontrol berobat, (98\%) keluarga tidak peduli dengan kesehatan penderita dan $(95 \%)$ keluarga tidak menanyakan kapan kembali melakukan kontrol berobat.

Menurut analisa penili tindakan keluarga yang kurang baik disebabkan oleh pengetahuan keluarga pasien yang kurang. Hal ini mengakibatkan perhatian kepada klien berkurang. Perhatian yang diberikan keluarga akan baik jika didukung dengan pengetahuan yang baik. Hasil wawancara dengan keluarga klien skizofrenia, sebagian besar mengatakan tidak mengetahui tentang pentingnya melakukan teratur kontrol berobat dan juga tidak mengetahui akibat dari putus berobat. Selain itu keluarga klien merasa bosan untuk mengambil obat karena sibuk dalam pekerjaan, rata-rata keluarga klien (69\%) pekerja swasta dengan rentang umur keluarga yaitu $26-60$ tahun.

\section{e. Hubungan Pengetahuan Keluarga dengan Keteraturan Berobat klien Skizofrenia}

Berdasarkan hasil penelitian dapat dilihat bahwa proporsi keluarga yang tidak teratur berobat lebih tinggi pada keluarga dengan pengetahuan rendah $(52,5 \%)$ dibandingkan dengan keluarga pengetahuan tinggi $(12,5 \%)$. Hasil uji statistik menggunakan uji chi square didapatkan nilai $p=0,000$.

Hasil penelitian ini di dukung oleh penelitian Ahmad Syaroni (2014) yang menyebutkan bahwa ada hubungan yang bermakna antara pengetahuan keluarga dengan keteraturan berobat klien skizofrenia dengan nilai $p$ sebesar 0,000 hubungan yang signifikan antara pengetahuan dan keteraturan berobat. Hasil penelitian ini sejalan dengan penelitian Friantoro (2013) yang menyebutkan bahwa ada hubungan yang bermakna antara pengetahuan keluarga terhadap keteraturan berobat klien skizofrenia dengan nilai $\mathrm{p}$ sebesar 0,015 . Hasil penelitian ini menjelaskan bahwa pengetahuan keluarga untuk merawat klien skizofrenia dibutuhkan untuk membantu proses penyembuhan klien skizofrenia.

Pengetahuan atau kognitif merupakan faktor yang sangat penting untuk terbentuknya tindakan seseorang sebab dari pengetahuan dan penelitian ternyata prilaku yang disadari oleh pengetahuan akan bertahan lebih lama dari pada perilaku yang tidak didasari oleh pengetahuan. Manusia mengembangkan pengetahuannya untuk mengatasi kebutuhan kelangsungan hidupnya (Nita, 2011).

Hasil penelitian ini menunjukkan bahwa adanya hubungan pengetahuan dengan keteraturan brobat klien skizofrenia. Hal ini juga dapat dilihat dari kecendrungan semakin tingginya pengetahuan yang dimiliki semakin patuhnya klien terhadap kontrol berobat.

Menurut analisa peneliti menunjukan bahwa pengetahuan keluarga tentang gangguan jiwa skizofrenia mempengaruhi penerimaan keluarga dalam merawat anggota keluarga skizofrenia di rumah. Pengetahuan keluarga tentang gangguan jiwa yang baik tentang masalah gangguan jiwa skizofrenia serta cara memperlakukan pasien skizofrenia dirumah dan melakukan kontrol berobat hal yang penting dalam proses penyembuhan. Namun tingkat pemahaman yang berbeda-beda antar individu yang menyebabkan pengetahuan masing-masing responden berbeda. Salah satu penyebab perbedaan pemahaman diantara responden disebabkan karena faktor pendidikan. Berdasarkan hasil penelitian yang memiliki pengetahuan rendah 46 responden $(57,5 \%)$. Oleh sebab kurangnya pengetahuan klien terhadap keteraturan berobat sangat berdampak terhadap kepatuhan klien dalam menjalani kontrol berobat. Seharusnya responden aktif dalam mencari informasi dan berkonsultasi dengan tenaga kesehatan guna menambah pengetahuan klien tentang keteraturan berobat, sehingga klien patuh dalam melakukan kontrol berobat secara teratur. 
Bahwa tenaga kesehatan tidak ada melakukan penyuluhan terhadap keluarga tentang skizofrenia. Pihak puskesmas kurang mengaktifkan kader tentang program kesehatan jiwa dan hanya terfokus pada ibu hamil dan bayi. Pada papan pengumuman tidak di temui leaflet tentang gangguan jiwa. Petugas kesehatan hanya memberikan obat saat pasien berkunjung ke puskesmas tanpa adanya evaluasi dan umpan balik bagi pasien yang tidak teratur berobat.

\section{f. Hubungan Sikap Keluarga dengan Keteraturan Berobat Klien Skizofrenia}

Berdasarkan hasil penelitian dapat dilihat bahwa proporsi keluarga yang sikap negatif lebih tinggi pada keluarga yang sikap positif $(43,8 \%)$ dibandingkan dengan keluarga yang memiliki sikap positif $(21,2 \%)$. Hasil uji statistik menggunakan uji chi square didapatkan nilai $p=0,005$.

Hasil penelitian ini di dukung oleh penelitian Tri yudha dkk 2014 yang menyebutkan bahwa ada hubungan yang bermakna antara sikap dengan keteraturan berobat klien skizofrenia dengan nilai $\mathrm{p}$ $(\mathrm{Sig})=0,000$, hal ini menunjukkan bahwa ada hubungan antara variabel sikap dan niat keluarga dalam melakukan kontrol pada penderita skizofrenia.

Sikap mempunyai peran penting dalam menjelaskan perilaku seseorang dalam lingkungannya, sikap seseorang terhadap suatu objek adalah perasaan mendukung atau memihak maupun perasaan tidak mendukung atau memihak pada objek tersebut. Dengan kata lain, seseorang yang yakin bahwa sebuah tingkah laku dapat menghasilkan outcome yang positif maka ia akan mempunyai sikap yang positif, dan jika sebuah tingkah laku dapat menghasilkan outcome negatif maka ia akan memiliki sikap yang negatif.

Menurut analisa peneliti pada penelitian ini salah satu cara untuk memperbaiki sikap keluarga adalah memberikan dukungan atau merawat pasien skizofrenia dengan meningkatkan pengetahuan keluarga terlebih dahulu karena sikap dan perilaku seseorang akan ditentukan oleh tingkat pengetahuan yang dimiliki, sehingga seseorang dapat berperan dalam upaya melakukan keteraturan berobat. Penelitian yang di lakukan di Puskesmas Lubuk Buaya Padang tentang gangguan jiwa, terlihat bahwa tenaga kesehatan tidak ada melakukan penyuluhan terhadap keluarga, maupun dari pihak Puskesmas kurang mengaktifkan kader, dan tidak mambagikan leafleat tentang gangguan jiwa pada saat pasien atau keluarga datang berobat ke Puskesmas Lubuk Buaya Padang. Apabila klien tidak melakukan kontrol berobat pihak puskesmas tidak melakukan home visit ke rumah, dan obat hanya di berikan apabila ada kunjungan berobat ke puskesmas.

Menurut peneliti sikap keluarga klien gangguan jiwa ini harus beralih kearah yang positif, keluarga seharusnya meluangkan waktu untuk mencari informasi mengenai gangguan jiwa dan memahami dampak tersebut bisa mengubah pandangan keluarga untuk bersikap positif terhadap keteraturan berobat klien skizofrenia. Pihak puskesmas sebaiknya memberikan pendidikan kesehatan dan motivasi pada keluarga pasien dengan skizofrenia untuk selalu mengontrol dan mengawasi penderita minum obat. Dukungan yang di berikan pihak puskesmas dapat meningkatkan sikap positif pada keluarga.

\section{g. Hubungan Tindakan Keluarga dengan Keteraturan Berobat Klien Skizofrenia}

Berdasarkan hasil penelitian dapat dilihat bahwa proporsi keluarga yang tindakan tidak baik lebih tinggi pada keluarga dengan tindakan baik $(42,5 \%)$ dibandingkan dengan keluarga tindakan baik $(22,5 \%)$. Hasil uji statistik menggunakan uji chi square didapatkan nilai $p=0,004$.

Hasil penelitian ini di dukung oleh penelitian Regina dkk (2014) yang menyatakan bahwa ada hubungan yang bermakna antara tindakan keluarga dengan keteraturan berobat klien skizofrenia dengan nilai $p 0,004$. Penelitian ini sejalan dengan penelitian Vinami Yulian dkk (2013) didapatkan hubungan antara support system keluarga dengan kepatuhan berobat klien rawat jalan di RSJ Surakarta dengan $p$-value= 0,000 yang artinya ada hubungan yang bermakna antara support system keluarga dengan kepatuhan berobat klien rawat jalan di rumah sakit jiwa daerah Surakarta.

Perilaku keluarga dalam membawa klien skizofrenia patuh berobat agar klien mampu melakukan komunikasi dengan orang lain, mampu memenuhi kebutuhan sehari-hari secara mandiri dan meminimalkan terjadinya kekambuhan. Kepatuhan klien dalam pengobatan dapat dimaksimalkan dengan meningkatkan dukungan keluarga yang mendukung 
agar klien semakin patuh dalam menjalani pengobatan sehingga klien dapat bersosialisasi atau berkomunikasi dengan orang lain serta dapat menjalani aktivitas secara mandiri.

Hasil penelitian menunjukkan bahwa pada tindakan keluarga yang tidak baik sebanyak $(52,5 \%)$ keluarga yang tidak pernah memberikan informasi terhadap klien skizofrenia dan tidak mengingatkan terhadap kepatuhan berobat. Oleh karena itu keluarga sangat berperan penting dalam proses keteraturan berobat klien skizofrenia. Keluarga diharapkan berperan aktif dalam mencari informasi mengenai gangguan jiwa dan akibat dari ketidakteraturan berobat, keluarga harus mengingatkan selalu klien agar rutin dalam melakuakan kontrol berobat dan mendampinggi klien dalam pengambilan obat. Keluarga memberikan dukungan penghargaan dengan memberikan pujian saat klien kontrol berobat, sehungga klien bisa terus termotivasi untuk patuh terhadap pengobatan.

Pada umumnya jika seseorang memiliki sistem pendukung yang kuat, kerentangan terhadap penyakit mental akan rendah dukungan psikososial keluarga memiliki peranan penting untuk membantu seseorang dengan keadaan terpuruk karena keluarga merupakan suatu unit pelayanan dan masalah keluarga saling berkaitan serta saling mempengaruhi antar sesama anggota keluarga. Dukungan psikososial tergantung pada lingkungan sosial dimana individu tersebut berada dalam keluarga dan komunitasnya. Seseorang dengan dukungan psikososial keluarga tinggi mempunyai keyakinan bahwa mereka dicintai, diperhatikan dan menjadi bagian dari keluarga.

Menurut peneliti tindakan keluarga merupakan sangat penting bagi penderita gangguan jiwa, keluarga dapat melindunggi penderita dari kekambuhan dan membawa penderita untuk melakukan kontrol berobat ke puskesmas. Berdasarkan penelitian yang peneliti lakukan di puskesmas Lubuk Buaya Padang terlihat beberapa orang sekitar 15\% gangguan jiwa melakukan pengambilan obat secara mandiri, kebanyakan pengambilan obat di dampinggi keluarga dan keluarga sendiri yang datang ke puskesmas untuk mengambil obat penderita gangguan jiwa. Di puskesmas Lubuk Buaya Padang obat di berikan oleh tenaga kesehatan apabila penderita atau keluarga datang mengambil obat.

Pihak Puskesmas sebaiknya mengaktifkan kader setempat dalam memberikan pengetahuan dan motivasi kepada keluarga skizofrenia sangatlah di butuhkan. Evaluasi atau dukungan yang baik terhadap pasien yang tidak melakukan pengobatan dalam bentuk home visit sangatlah efektif untuk diterapkan

\section{KESIMPULAN}

Berdasarkan hasil penelitian yang telah dilakukan peneliti tentang hubungan perilaku keluarga dengan keteraturan berobat klien skizofrenia puskesmas Terdapat lebih dari separuh $(65,0 \%)$ responden yang tidak teratur berobat, Terdapat lebih dari separuh $(57,5 \%)$ responden dengan pengetahuan rendah, Terdapat lebih dari separuh $(55,0 \%)$ responden dengan sikap negatif, Terdapat lebih dari separuh $(52,5 \%)$ responden dengan tindakan yang tidak baik, Ada hubungan pengetahuan, sikap dan tindakan keluarga dengan keteraturan berobat pasien skizofrenia.

\section{UCAPAN TERIMA KASIH}

Proses pelaksanaan penelitian ini dimana peneliti tidak terlepas dari kesulitan dan hambatan, namun berkat bantuan dan kerjasama dari berbagai pihak akhirnya penelitian ini dapat diselesaikan. Kami mengucapkan terima kasih kepada Ketua STIKes, UPPM STIKes Alifah Padang dan Kepala Puskesmas Lubuk Buaya Padang beserta Tenaga Keperawatan.

Dengan segala kerendahan hati semoga hasil penelitian ini berguna dan bermanfaat bagi pihak-pihak yang memerlukan.

\section{DAFTAR PUSTAKA}

Azwar, S. (2005). Reabilitas \& Validitas. Yogyakarta: pustaka pelajar.

Benyamin bloom (1908). Perilaku kesehatan jiwa. Jakarta: EGC

Depkes, RI (2011). Profil kesehatan Indonesia 2011. Jakarta : diakses 4 Februari 2017.

Direja S,H, Ade. 2014. Asuhan keperawatan jiwa, cetakan 1, Yogyakarta : Nuha medika.

Prabowo eko, (2011). Asuhan keperawatan jiwa. Jakarta: salemba humika.

Green, Lawrance w. (2007). Perencanaan pendidikan kesehatan : diterjemahkan oleh maudy, dkk. Jakarta : FKM-UI.

Keliat, Budi.A.(2011). Keperawatan kesehatan jiwa komunitas. Jakarta : EGC. 
Keliat, Budi.A.(2016).Konsep gangguan jiwa. Jakarta : EGC

Kazadi et al.(2008). Stress Apparaisal And coping, new york : springer publisher comp.

Lane, (2013). Kepatuhan berobat. http// digilib. Litbang. Depkes.go.id diperoleh tanggal 10 mei 2009.

Masnona, dkk (2013). Hubungan dukungan keluarga dengan kepatuhan berobat klien skizofrenia di poliklinik GMO RSJ PROF.DR.HB SA'ANIN PADANG 2013.

Marilyn M. Friedman (2011). Keperawatan keluarga : Teori \& praktik.Edisi3. jakarta : EGC

Notoatmodjo, S. (2007). Promosi Kesehatan \& ilmu perilaku. Jakarta: penerbit Rineka Cipta.

Notoatmodjo, S. (2010). Ilmu perilaku kesehatan. Jakarta : PT Rineka Cipta.

Riskesdas, 2013. Riset kesehatan dasar. Diakses pada tanggal 1 desember 2017. Jakarta : kementrian kesehatan RI

Regina, I,dkk (2013). Hubungan Dukungan Keluarga Dengan Kepatuhan Kontrol Berobat Pada Klien Skizofrenia di Rumah Sakit Jiwa Daerah DR.Amino Gondohutomo Semarang

Riska Ratnawati (2016). Hubungan dukungan keluarga dengan kepatuhan berobat penderita skizofrenia. Stikes bakti husada.

Sri Wulansih, (2008). Hubungan Antara Tingkat Pengetahuan dan Sikap Keluarga Dengan Kekambuhan Pada Pasien Skizofrenia Di RSJD Surakarta.

Suryati, dkk (2008). Keperawatan jiwa. Jakarta: EGC

Surya direja, (2011). Keperawatan jiwa skizofrenia. Bandung : EGC

No, 18 Tahun 2014. Kesehatan jiwa. Jakarta selatan diakses pada tanggal 7 agustus 2014 .

Lestari fitri,dkk (2010). Hubungan dukungan keluarga dengan kepatuhan berobat klien skizofrenia dipuskesmas telaga kabupaten gorontalo.
Willy F. Maramis.(2004). Catatan ilmu kedokteran jiwa. Surabaya : Airlangga Universitas Press.

Yosep, Ilus,2007. Keperawatan jiwa. Bandung : PT Refika Aditama.

Yosep, I.2010. keperawatan jiwa, edisi revisi. Bandung: PT Refika Aditama.

Yuliantika, (2012). Hubungan antara support system keluarga dengan kepatuhan berobat klien rawat jalan dirumah sakit jiwa daerah surakarta 